Article

\title{
Monitoring Littoral Platform Downwearing Using Differential SAR Interferometry
}

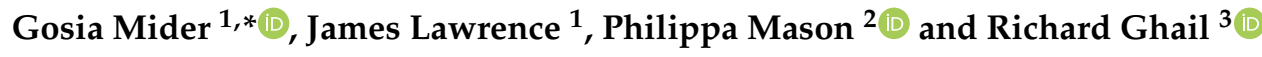 \\ 1 Department of Civil and Environmental Engineering, Imperial College London, London SW7 2AZ, UK; \\ j.lawrence@imperial.ac.uk \\ 2 Department of Earth Science and Engineering, Imperial College London, London SW7 2AZ, UK; \\ p.j.mason@imperial.ac.uk \\ 3 Department of Earth Sciences, Royal Holloway, University of London, Egham, Surrey TW20 0EX, UK; \\ richard.ghail@rhul.ac.uk \\ * Correspondence: malgorzata.mider16@imperial.ac.uk; Tel.: +44-(0)-734-227-1426
}

Received: 14 August 2020; Accepted: 3 October 2020; Published: 6 October 2020

\begin{abstract}
A methodology for the remotely sensed monitoring, measurement and quantification of littoral zone platform downwearing has been developed and is demonstrated, using Persistent Scatterer Interferometric Synthetic Aperture Radar data and analysis. The research area is a $30 \mathrm{~km}$ section of coast in East Sussex, UK. This area combines a range of coastal environments and is characterised by the exposure of chalk along the cliffs and coastal platform. Persistent Scatterer Interferometry (PSI) has been employed, using 3.5 years of Sentinel-1 SAR data. The results demonstrate an average ground level change of $-0.36 \mathrm{~mm} \mathrm{a}^{-1}$ across the research area, caused by platform downwearing. Protected sections of coast are downwearing at an average of $-0.33 \mathrm{~mm} \mathrm{a}^{-1}$ compared to unprotected sections, which are downwearing more rapidly at an average rate of $-1.10 \mathrm{~mm} \mathrm{a}^{-1}$. The material properties of the chalk formations in the platform were considered, and in unprotected areas the weakest chalk types eroded at higher rates $\left(-0.66 \mathrm{~mm} \mathrm{a}^{-1}\right)$ than the more resistant formations $\left(-0.53 \mathrm{~mm} \mathrm{a}^{-1}\right)$. At a local scale, results were achieved in three studies to demonstrate variations between urban and rural environments. Individual persistent scatterer point values provided a near-continuous sequence of measurements, which allowed the effects of processes to be evaluated. The results of this investigation show an effective way of retrospective and ongoing monitoring of platform downwearing, erosion and other littoral zone processes, at regional, local and point-specific scales.
\end{abstract}

Keywords: InSAR; coastal monitoring; platform downwearing; persistent scatterer interferometry; chalk erosion

\section{Introduction}

Approximately $10 \%$ of the world's population lives in coastal zones [1], and, as a result of weather patterns, climate change, rising sea levels and anthropological activities, many coastal communities are at risk of the effects of erosion and flooding. Climate change models predict that the risks in coastal environments will only increase, and a climate report by Howard and Palmer [2] suggests that global sea levels may rise between $0.6-1.7 \mathrm{~m}$ by the year 2300 . Identifying reliable and repeatable methods of monitoring the state of littoral zones is vital if we are to understand and calculate the impact of coastal processes and climate change on our coastal environments and communities. Platform downwearing has been used as a proxy for understanding the evolution of the littoral zone in a number of areas and could therefore potentially form a very useful coastal planning tool, especially for coastal communities. It has been studied extensively, and results have been published in multiple papers, including Dornbusch and Moses [3], Moses and Robinson [4], Cullen and Verma [5] or Swantesson [6]. 
This study focused on the chalk cliffs and platform of East Sussex because chalk is considered a very weak to weak rock (of a strength between 1-25 MPa) which is susceptible to rapid erosion and weathering [7] and is therefore an ideal target for monitoring coastal erosion and processes that are quantifiable over relatively short time periods and can then be used as analogues for other coastal environments. This particular section of chalk coast has been the subject of multiple studies of shore platform erosion over many years, and thus forms the most suitable site for this research.

Interferometric Synthetic Aperture Radar (InSAR) is a remote sensing technique that provides reliable ground surface measurements over relatively long time periods with millimetre precision (when used to create multitemporal long time series methods) along the sensor's 'line-of-sight' (LOS) ([8]). InSAR has been actively used since the early nineties (e.g., $[9,10])$ to monitor geological processes and has been continuously employed to analyse processes like tectonic movements [11] and landslides [12-14] or been used to monitor salt mines and ground deformation [15]. The European Space Agency's (ESA) satellites, Sentinel-1A and -1B, have been operating since 2014 and 2016, respectively, and provide freely available SAR data. Each satellite acquires data with a 12-day repeat, but, since -1A and $-1 \mathrm{~B}$ are on synchronous orbits separated by 180 degrees, they provide information with a six-day repeat period. This routine image acquisition frequency provides an unparalleled ability for long-term monitoring, accuracy and data accessibility. The use of long time series (multitemporal) InSAR analysis provides a tool for monitoring small-scale ground deformation and change in a range of different environments, such as for tunnelling projects in urban environments [16-21], building subsidence monitoring [22], surface deformation detection [23], mapping interactions between geology and urban development [24], monitoring $\mathrm{CO}_{2}$ storage [25], or monitoring agricultural areas [26]. Being an active sensing system, SAR imaging operates independently of the sun and weather, giving continuous information without disturbances of rain or lack of sunlight. Recent methods of data processing can provide information on the ground movements on a millimetre scale, which is within the expected resolution of platform downwearing rates. Persistent Scatterer Interferometry (PSI) can provide precise and frequent measurements over long time periods, over large areas of interest, and with a relatively short revisit period, none of which has yet been achievable in conventional studies of platform erosion. This work investigates the effectiveness of the PSI analysis of coastal chalk platforms and compares it to current methods to establish its effectiveness as a coastal monitoring tool.

\section{Study Region}

This study is focused on a $30 \mathrm{~km}$ stretch of chalk littoral zone between Brighton (TQ 31272 0418) and Eastbourne (TV 60749 98791) in East Sussex (Figure 1). It is well known for its prominent cliffs, which dominate this coastline. Chalk is a soft rock prone to rapid erosion and weathering within short time frames (e.g., over 2-5 years), making it an excellent analogue that can be compared to other more resistant rock types that erode less easily and where coastal processes operate over much longer time scales. In addition, a range of urban-protected and rural-unprotected littoral zone environments exist and can be studied in this area [27]. Moses [28] estimates that about half the British Isles' coastline is formed of rocks that are particularly prone to cliff retreat and shore platform downwearing. The coast of East Sussex is known to have a large tidal range of more than $6 \mathrm{~m}$, leading to the development of a large and vulnerable intertidal zone. 


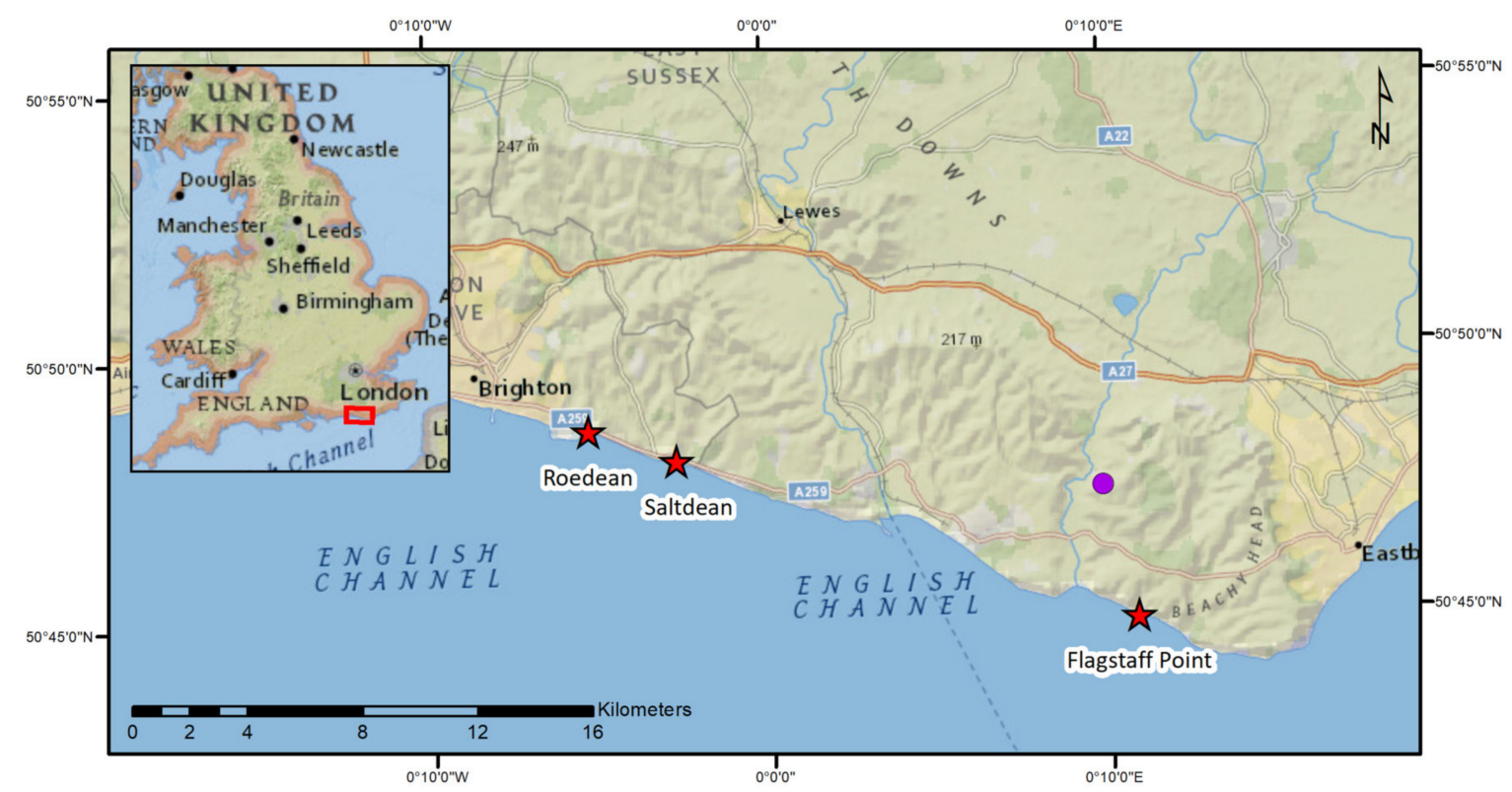

Figure 1. Map of the study area. Location of research sites marked with red stars. Purple circle represents the location of the reference point that has been used for PS processing in this study. Overlain onto ArcGIS Online National Geographic World Map (Sources: National Geographic, Esri, Garmin, HERE, UNEP-WCMC, NASA, ESA, METI, NRCAN, GEBCO, NOAA, increment P Corp.).

Chalk crops out over extensive areas of the UK and northwest Europe and can be observed in large parts of southern and northeastern England from Yorkshire in the North East to Dorset in the South [29]. Chalk can be described as a micritic limestone or fine-grained calcareous mudstone. In reality, it is much more complex, consisting of various sediments, including marls, flint bands, marly chalks, shell-rich sediments and many others [30]. Pure, white chalk is often made of up to $98 \%$ calcium carbonate, which is mostly a submicroscopic skeletal debris—coccolithic algae-but some chalk layers can contain only about $20-30 \%$ of carbonate and are known as marly chalks [29]. Chalk is a soft rock that is easily weathered in multiple ways, by saturation weakening in water or oil, by frost, by chemical dissolution or by salt weakening [31,32].

In the UK, southern province chalk has been divided into several formations based on lithostratigraphy (Figure 2). The chalk formations exposed at the coast between Brighton and Eastbourne, which are the focus of this investigation, are the Newhaven, Seaford and Lewes Nodular Chalk (Figure 3). Newhaven Chalk contains the highest amount of sheet flints with common marl seams [30]. It is usually low- to medium-density, very weak to weak and with a high-porosity [33]. Seaford Chalk is considered to be low-density, with a medium porosity and weak formation that is easily susceptible to frost and quite easy to erode, with laterally continuous nodular flints commonly forming prominent marker beds [34]. Lewes Nodular Chalk is stronger than the other two and not as easy to break apart; it is, however, more brittle [30], with a higher porosity and with nodular flints within its structure [34,35]. 


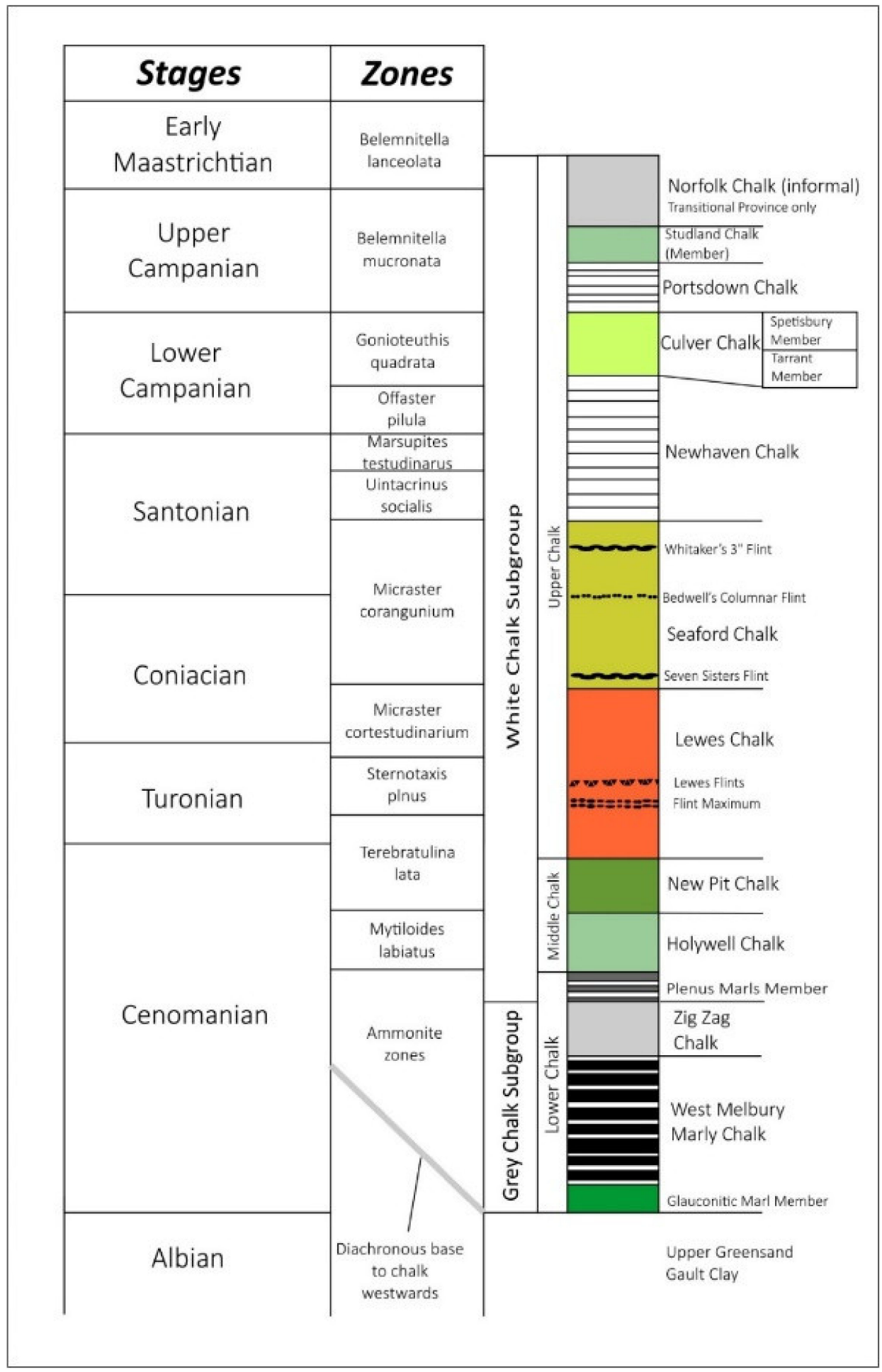

Figure 2. Lithostratigraphic column of the Chalk Group, adapted from Mortimore et al., 2004 [34]. 


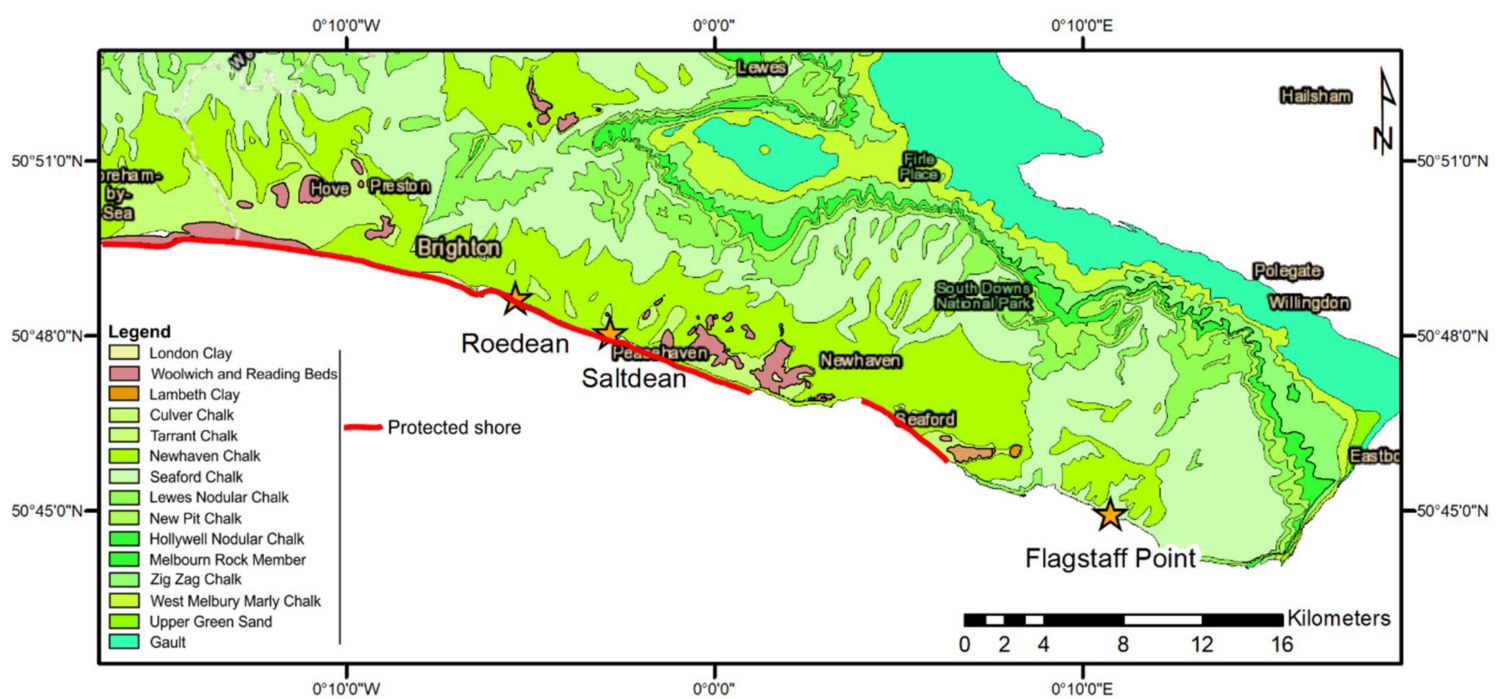

Figure 3. Bedrock geology of East Sussex, available on Edina DigiMap online (updated 2013 by BGS) with the protected areas of the shore marked in red (Service Layer Credits: Esri, HERE, Garmin, (C) OpenStreetMap contributors and the GIS User Community).

\section{Existing Platform Downwearing Measuring Methods}

A wide range of methods have been developed to monitor and measure platform downwearing, including both direct and indirect measurements. Direct methods are heavily focused on point scale information over a set period of time, particularly the Micro-Erosion Metre (MEM) developed by Robinson [36]. MEMs are small triangular instruments (Figure 4A (reprinted from Stephenson and Finlayson, 2009: p.55 [37])) that are securely fixed to a rock platform surface, and the height is recorded by lowering a probe onto the rock surface [38]. The rate of downwearing is measured by calculating the difference between two consecutive measurements in time. Whilst the instrument is accurate, with a dial gauge resolution of down to $0.001 \mathrm{~mm}$, the MEM can only record data at this one point-position. In addition, the equipment must remain in situ with the potential of being damaged, the recording of measurements is time consuming and therefore costly, and the MEM must be operated by a trained individual. Lastly, the MEM can monitor neither continuously nor in inclement weather conditions.

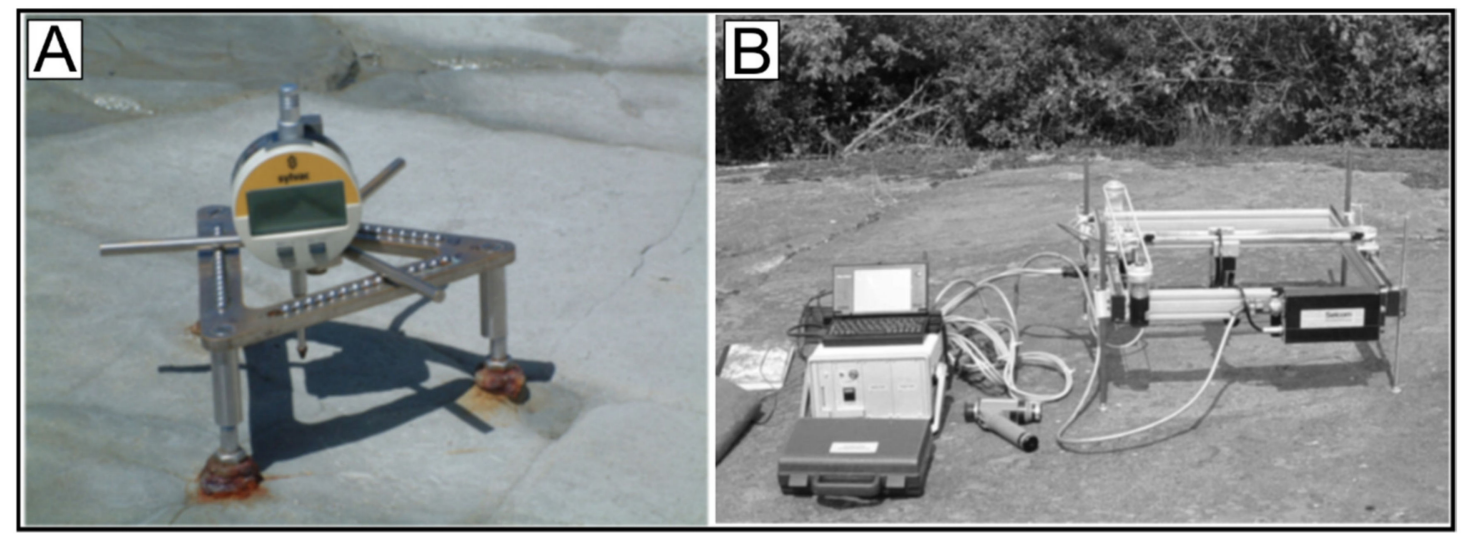

Figure 4. Current existing tools for platform downwearing. Photograph (A): MEM tool attached to the platform (image reprinted from Stephenson and Finlayson, 2009: p.55 [37]), photograph (B): laser scanning equipment (image reprinted from Swantesson, 2005: p.16 [39]).

Noncontact measurement methods are achievable using a portable, tripod-mounted, Terrestrial Laser Scanner (TLS) [6] (Figure 4B (reprinted from Swantesson, 2005: p.16 [39])). Swantesson and 
Moses [37] used this technique to measure downwearing on small platform surface areas of $40 \times 40 \mathrm{~cm}$, to a height resolution of $0.025 \mathrm{~mm}$. The laser probe moves and scans in the $\mathrm{x}$ - and $\mathrm{y}$-directions 10-15 cm above the rock surface. Unlike the MEM, the TLS can generate micromaps from multiple (up to 100 million) measurement points and can measure and quantify the surface roughness [4]. One limitation to the TLS approach is that the instrument is not fixed into the rock surface, leading to repeat measurement accuracy errors of up to $2 \mathrm{~mm}$ when compared to MEM techniques [37]. There are many portable TLS instruments available, but those which are most suitable can be quite heavy (ca. $30 \mathrm{~kg}$ ) and often require two operators to carry and set them up. In addition, the TLS can measure only a limited area in each survey before the point density and dataset volume become prohibitive.

The TLS technique has similar limitations and risks as the MEM. It cannot easily monitor continually over a period, a trained operator is required on-site at all times, measurement surveys are time-consuming and therefore costly, and they are weather-dependent.

Laser scanning (LS) tools can also be mounted on aircraft and drones; airborne Light Detection and Ranging (LiDAR) surveys can provide detailed information on platform downwearing over large areas and can be repeated at regular intervals, but they often lack the accuracy of TLS and MEM. Airborne LS accuracy depends mainly on the flying height and speed, and data need to be calibrated precisely with prior surveys [4]. These limitations, combined with the need for trained operators, mobilisation logistics and regulations, make them prohibitively expensive.

Dornbusch and Moses [3] used 1:5000 scale aerial photography and photogrammetric methods to calculate the rates of platform downwearing. Two photographic aerial surveys were compared, one from 1973 and the other from 2001. These air photographs were taken as part of an Annual Beach Monitoring survey with a ground resolution of $\sim 7 \mathrm{~cm}$ and $11 \mathrm{~cm}$ for the photo from 1973 and 2001, respectively. The Ground Control Points (GCPs) were collected with a differential GPS, with a horizontal and vertical accuracy of $\pm 0.2 \mathrm{~m}$. A comparison of features in the photographic sets was difficult in some areas because of cliff erosion, the construction of new coastal defences since 1973 and groyne-deterioration since 1973. Their method compared high-resolution stereo photographs of the area of interest to extract a Digital Elevation Model (DEM) with a horizontal ground resolution of $0.1 \mathrm{~m}$ (to present a small-scale topographic variation of the platforms) and with a $\pm 0.2 \mathrm{~m}$ vertical accuracy, which came from a set of elevation points provided by the Environment Agency. This method was cost-effective, but it required high-accuracy GCPs and archived sets of photographs for analysis, in addition to regular repeated surveys. Rarely are there suitable archived photographs that allow for the required retrospective comparison, so continuous information about the erosion rates can only be performed from the present time onwards. Such low-altitude, high-accuracy, high-detail aerial photographic surveys are also costly to undertake.

These platform downwearing methods have all been used along the coast of East Sussex; studies have been focused on a stretch of coast east of Brighton and Hove. At this site, MEM measurements have been recorded since the 1980s and have been used to estimate platform downwearing, especially adjacent to 'groynes'. Ellis [40] calculated an average downwearing of $3.5 \mathrm{~mm} \mathrm{a}{ }^{-1}$, based on their research performed between 1981-1983 The work of Dornbusch and Robinson [41] employed two photographic surveys (based on photographs from 1973 and 2001) and calculated an overall platform downwearing rate of $0.1-0.9 \mathrm{~mm} \mathrm{a}^{-1}$ near Roedean (TQ 34667 03136) and 3.00-25.4 $\mathrm{mm} \mathrm{a}^{-1}$ near Hope Gap (TV 51041 97373). They also identified a significant variation and the stochastic nature in downwearing between sites (Table 1). Swantesson and Moses [37] compared MEM- and TLS-derived downwearing rates at several sites, including some in East Sussex; erosion was observed to operate at irregular rates across the platforms, and the greatest downwearing rates were observed in closest proximity to the cliffs. Even within the very small survey areas (of $200 \times 200 \mathrm{~mm}$ or $240 \times 240 \mathrm{~mm}$ ), variations in the downwearing rate were observed. Swantesson and Moses [37] also discussed the differences in the downwearing rate over time, citing an example of very small changes at Peacehaven (TQ 41207 01477) between the summers of 1999 and 2000, while in the year 2001 an almost 
ten times greater erosion was measured using a TLS survey, although the authors do not provide quantitative values.

Table 1. Surface erosion comparison between different measurement methods. Data in the table collated in Dornbusch and Robinson [42].

\begin{tabular}{|c|c|c|c|c|}
\hline Location & Grid Reference & $\begin{array}{l}\text { Photogrammetry } \\
{\left[\mathrm{mm} \mathrm{a}^{-1}\right]}\end{array}$ & $\begin{array}{c}\text { MEM Measurements } \\
{\left[\mathrm{mm} \mathrm{a}^{-1}\right]}\end{array}$ & $\begin{array}{l}\text { Laser Scanning } \\
\quad\left[\mathrm{mm} \mathrm{a}^{-1}\right]\end{array}$ \\
\hline Roedean & TQ 3466703136 & -0.9 to -0.1 & -3.5 & \\
\hline Peacehaven & TQ 4120701477 & -4.9 to -1.0 & -1.5 & -0.3 \\
\hline Hope Gap & TV 5104197373 & -20 to -6 & & \\
\hline
\end{tabular}

\section{Methods}

\subsection{InSAR Methodology}

The SAR data used in this study have been processed with the SARScape PS module, which implements a PSI methodology, previously described in numerous publications [43-46]. The SAR data were acquired by two European Space Agency (ESA) satellites, Sentinel-1A and Sentinel-1B, which have been in orbit since 2014 and 2016, respectively. These two satellites orbit the Earth and acquire images routinely, each with a frequency of 12 days but separated by $180^{\circ}$, resulting in a six day return period for any one area of interest. The satellites use a C-band frequency of $5.404 \mathrm{GHz}$ and a central wavelength of $5.54 \mathrm{~cm}$. Together, Sentinel-1A and -1B have the potential to detect surface deformation with millimetre accuracy when processed using multitemporal, long-time-series approaches such as PSI. Interferometric Wide swath data, which is the main acquisition mode over land, are used here and have a spatial resolution of $5 \times 20 \mathrm{~m}$ across a $250 \mathrm{~km}$ swath. Data used in this project come from track 132 , in ascending orbit.

PSI requires the processing of at least 33 scenes to produce a time series of ground deformation measurements with acceptable coherence and precision [43]. By processing a large number of scenes, the error and noise are reduced, producing clearer and more accurate results. Persistent or permanent scatterers (PS) represent strong reflectors, are usually seen in a SAR image as bright points and are pixels of the image that are coherent over a long time [45]. They are typically produced by structures such as buildings (and other artificial structures) or rocky surfaces that are stable or only gradually moving over a long period of time. When the dimension of the PS is smaller than the resolution cell, the coherence is good, even with interferograms with baselines greater than the decorrelation length. For these pixels, a submetre DEM accuracy can be reached, even if the coherence is low in the adjacent areas [45]. The data used in this study were processed with SARscape software (SARMap/Harris Geospatial) using a minimum coherence value of 0.65 , which provided a reasonable point density. Master image (reference image) is selected automatically during the first step of the SARScape PS processing procedure, and it is an image from 24/06/2017. PS points computed during the processing are referred to the reference point at the coordinates of TQ 5258601174 (see Figure 1).

Sentinel-1A and -1B acquire images at approximately the same local time each day, one in the morning and the other in the evening, but these imaging times do not always coincide with the same tide conditions. Since the shore platform is fully submerged at high tide, it is desirable to select only those SAR scenes acquired at or near times of low tide to ensure platform exposure. In this study, only scenes acquired within a two-hour window around low tide were selected for PSI processing. From the entire stack of 184 SAR scenes acquired in the 3.5 years of Sentinel-1A and -1B operations (07/03/2015 to 02/02/2019), 93 low-tide scenes were selected. The difference between low- and high-tide data (Figure 5, presenting the Flagstaff Point research site) led to an increase of PS points for the study area. Figure 5 shows an example of a fourfold increase from 233 PS points to 935 PS points generated for the same coherence threshold and data quality. This improved PS data quantity enabled the measurement and interpretation of ground level change across the entire shore platform. 


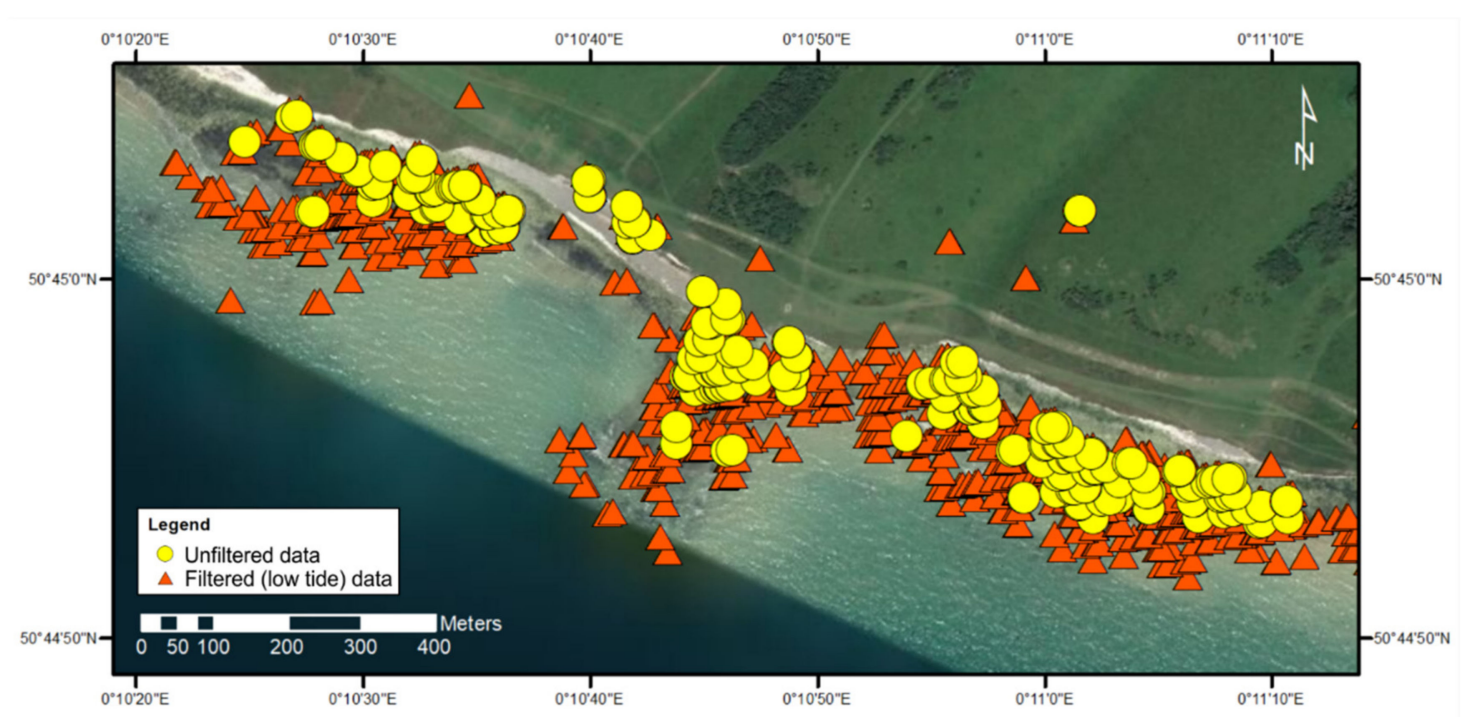

Figure 5. Flagstaff Point research site showing an example of the difference in the point density between processed data from every scene recorded within the time period of interest (yellow circles) and processed data filtered to only include scenes when the tide was low (orange triangles). In this example, the unfiltered data produced only 233 PS points, whilst the data filtered to include the low tide produced 935 PS points. Data overlain on ArcGIS Online World Imagery (Service Layer Credits: Esri, HERE, Garmin, (C) OpenStreetMap contributors and GIS user community. Source: Esri, DitalGlobe, GeoEye, Earthstar Geographics, CNES/Airbus DS, USDA, USGS, Aero GRID, IGN and GIS User Community).

Data from SARScape (ENVI software/Harris Geospatial) was exported into Excel, and a moving average with a step of seven scenes was used to smooth the data, show trends and improve the visual analysis, as well as to discard the noise from the results and present the data clearly. Maps of the average velocity were created in ArcGIS, using Inverse Distance Weighted (IDW) average interpolation, with a fixed search radius of $200 \mathrm{~m}$ and a power of 2. The results for the case study discussion are displayed on ArcGIS images, with the PS data points presented as the time series that were created in Excel for the selected areas.

When analysing the PS time series, it is noticeable that fewer scenes are available for the year 2015 since only one satellite was in orbit at this time, causing longer gaps between acquisitions as well as when using scenes only acquired during low tide; this means that the results over that year would be less useful for monitoring the platform downwearing.

The research area covers both urban and rural environments, since the former include engineered coastal platform defences such as groynes, seawalls and splash-walls, and since in general the latter have no defences. This division assists in the understanding of the spatial variations in the detected ground level change and in gaining an appreciation of the effectiveness of the coastal defences.

\subsection{Research Sites Chosen for Demonstration of Platform Downwearing}

Three research sites were chosen to demonstrate the measured ground level on the Sussex coast, which we have interpreted as being caused by platform downwearing (Figure 1). These sites include Roedean (TQ 34731 02984) and Saltdean (TQ 37758 01964), which represent urban environments where coastal defences are in place and where other platform downwearing investigations have been undertaken (Table 1). The third site is at Flagstaff point (TV 53844 96674), which lies on the coastal stretch known as 'Seven Sisters'; this was selected to represent an unprotected rural coast and shore platform where natural erosional processes occur unhindered.

The Roedean site (Figure 6) covers an area of $140 \times 520 \mathrm{~m}$ and lies adjacent to the Brighton Marina. Defences installed here include a concrete undercliff walkway and seawall, a splash-wall, six groynes and a 'rip-rap' protection beyond the groyne area. The shore platform between the groynes 
is only exposed at low-tide times. The undercliff walkway is heavily used by walkers, cyclists and for recreational purposes, especially during the summer months.

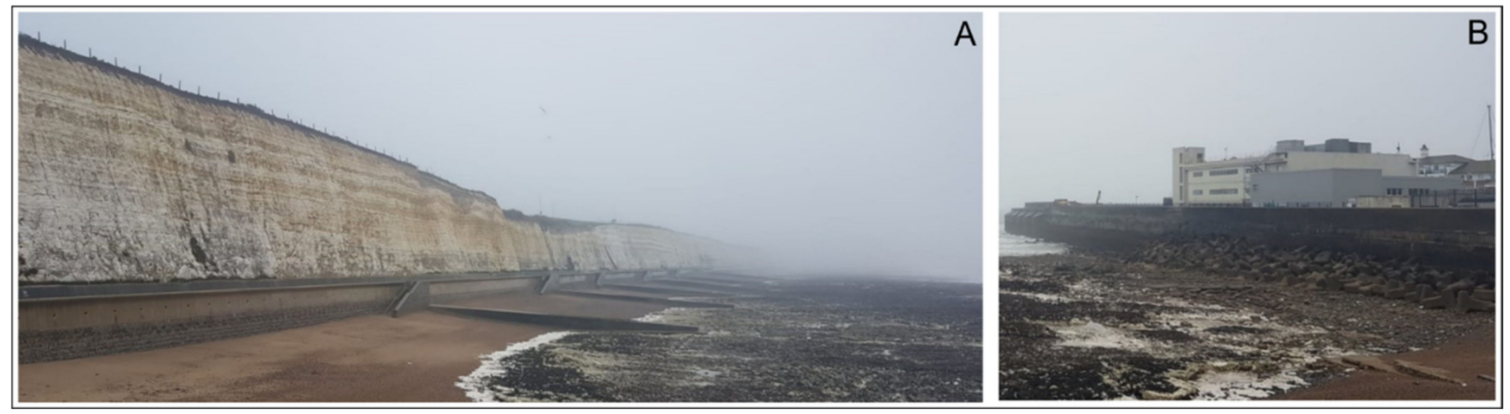

Figure 6. Roedean site at low tide. Photograph (A) showing the view looking east, visible groynes in the distance and sediment accumulating in between, with a chalk platform in front of the sediment. Photograph (B) looking southwest, showing the end of the Marina and a rip-rap shore protection in front.

The Saltdean site is $35 \times 335 \mathrm{~m}$ in size and is also characterised by a concrete undercliff seawall and undercliff walkway, splash-wall and four 'rip-rap' groynes (Figure 7). This is another popular area used by residents and tourists throughout the year.

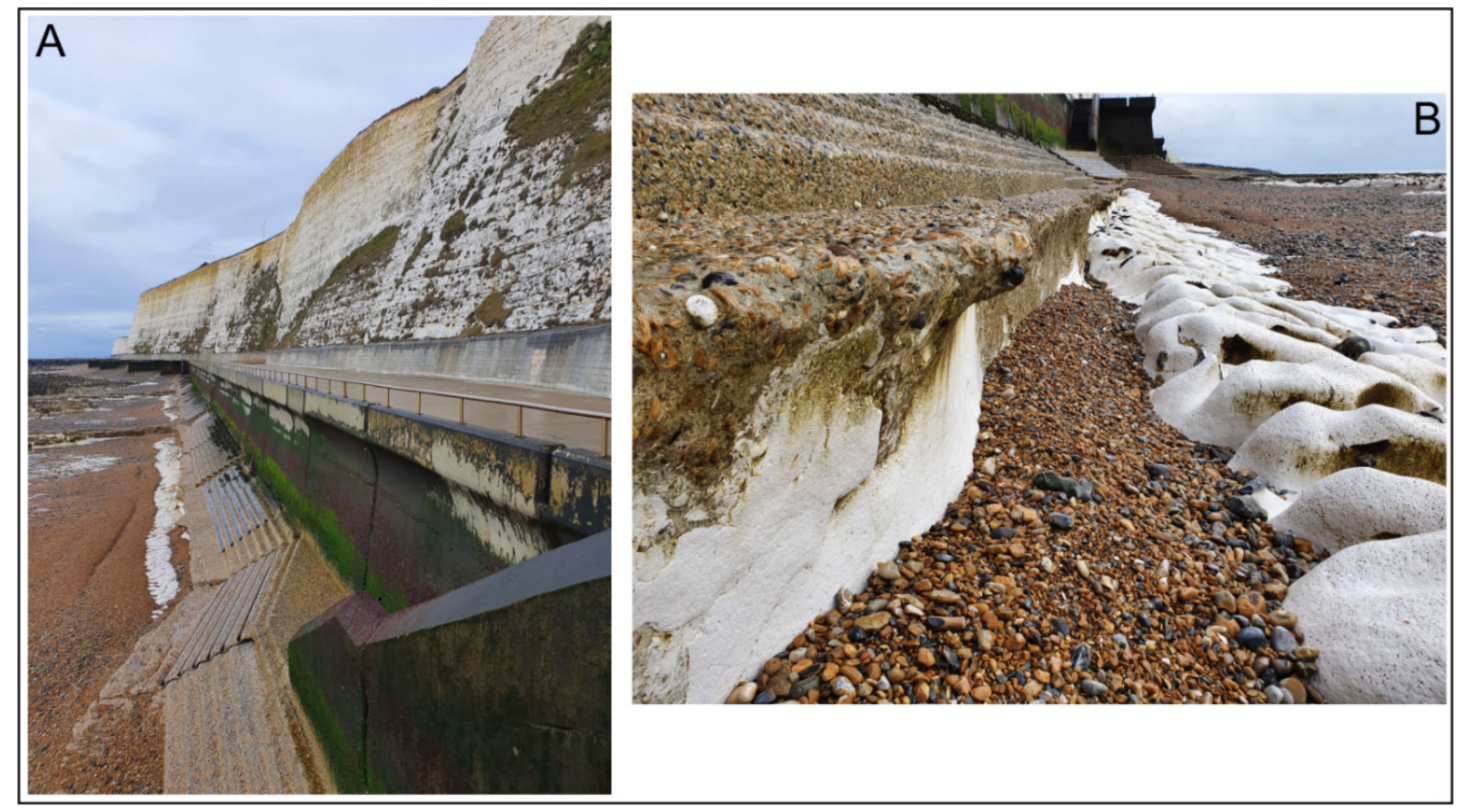

Figure 7. Undercliff Walk in Saltdean. Photograph (A) shows the splash wall, undercliff walk, seawall with small steps and the shingle beach in front of the steps. Photograph (B) presents part of the seawall directly on the shingle beach. Downwearing and erosion at the seawall steps have exposed the base of the seawall foundations and the underlying chalk. The bottom step has a slightly concave shape from continuous wave erosion.

The Flagstaff Point site represents a rural, unprotected shore platform and covers an area of $250 \times 320 \mathrm{~m}$ (Figure 8). The rocky shore platform below the cliff face is only fully exposed at the lowest low tide and is covered by very little shingle, which characterises it as a good source of PS points. 


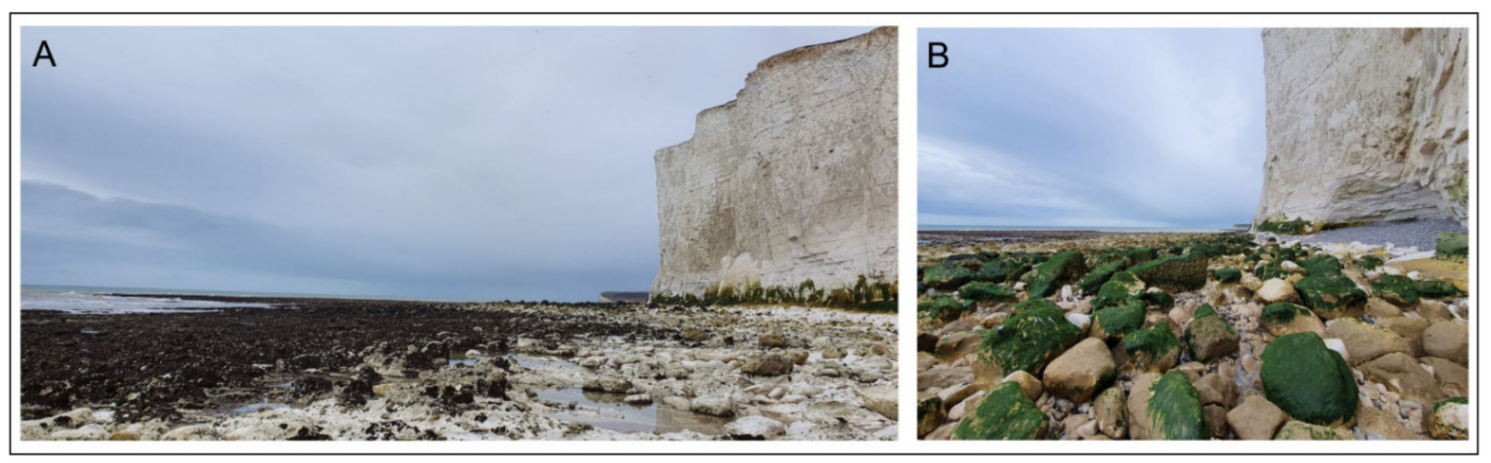

Figure 8. Flagstaff Point platform at low tide. Photograph (A) shows the spread of the platform in front of the cliff face, extending $200 \mathrm{~m}$ into the sea. Photograph (B) shows large chalk boulders spread on the platform, providing a good stable response to the radar waves.

\section{Results and Discussion}

The results are presented as time series plots, with the period of time over which the analysis was performed on the horizontal axis and the amount of ground movement in the line of sight (LoS) towards the satellite on the vertical axis.

\subsection{Regional Overview of the Results}

The PSI ground level change results for the littoral zone over the research area (Brighton-Eastbourne) are presented as an interpolated map of average LoS ground velocities per annum in Figure 9, as discussed previously in Section 4.1 on the InSAR Methodology. Figure 9A-C focuses on the area around the three research sites, providing local site-level detail. The maps plot interpolated PS data, which are irregularly distributed along the coastal zone in order to show the spatial patterns along the littoral zone.

Average movements are presented in Figure 9, where yellow to red colours show downward ground movement (LoS movement away from the sensor) in $\mathrm{mm} \mathrm{a}^{-1}$ and blue colours show upward ground movement (LoS movement towards the sensor) in $\mathrm{mm} \mathrm{a}^{-1}$. Ground level changes are spatially variable across the study area and not random, with changes occurring in spatially clustered patterns. Several areas are characterised by pronounced upward movements and others by similarly pronounced downward movements.

Across the region, a downward trend can be observed at an average rate of $-0.36 \mathrm{~mm} \mathrm{a}^{-1}$. The downward movement, which we interpret as platform downwearing, is much slower in urban areas $\left(-0.33 \mathrm{~mm} \mathrm{a}^{-1}\right)$ than in unprotected sections $\left(-1.10 \mathrm{~mm} \mathrm{a}^{-1}\right)$. Along the urban sections, the various man-made coastal protections could be slowing the platform downwearing. There are clearly defined zones where the ground level change occurs at a higher rate than elsewhere. Such areas occur at several locations near Brighton, Peacehaven and Saltdean. These regions are identified in the PSI ground movement map, suggesting that further investigation or maintenance work may be required. Stable regions with little ground level change are visible around Newhaven and Saltdean, suggesting that coastal defences are effective here or perhaps that these areas are less susceptible to downwearing.

The platform lithostratigraphy along the coast was been considered as a potential control on ground level change and platform downwearing (see Figure 3). The spatial average ground level change was calculated for each of the three formations exposed on the platform (Table 2). As expected, the more resistant Lewes Nodular Chalk $\left(-0.53 \mathrm{~mm} \mathrm{a}^{-1}\right)$ erodes more slowly than the softer Seaford Chalk $\left(-0.66 \mathrm{~mm} \mathrm{a}^{-1}\right)$ However, the Newhaven Chalk erodes more slowly $\left(-0.40 \mathrm{~mm} \mathrm{a}^{-1}\right)$ but has similar material properties to the Seaford Chalk [34]. The Newhaven erodes $-0.25 \mathrm{~mm} \mathrm{a}^{-1}$ slower than the Seaford, and $0.13 \mathrm{~mm} \mathrm{a}^{-1}$ slower than the Lewes Nodular Chalk Formation. However, the Newhaven Chalk only occurs along urban sections of cliff, whereas the Lewes Nodular Chalk and Seaford Chalk occur predominantly along rural settings, suggesting that coastal engineering 
has a greater influence on downwearing than rock formation does. While these results are close to the accuracy limits for PSI, they are based on a long time series (3.5 years of data) of continuous ground movement with a consistent downward trend and are hence considered reliable estimates (see Section 5.2).
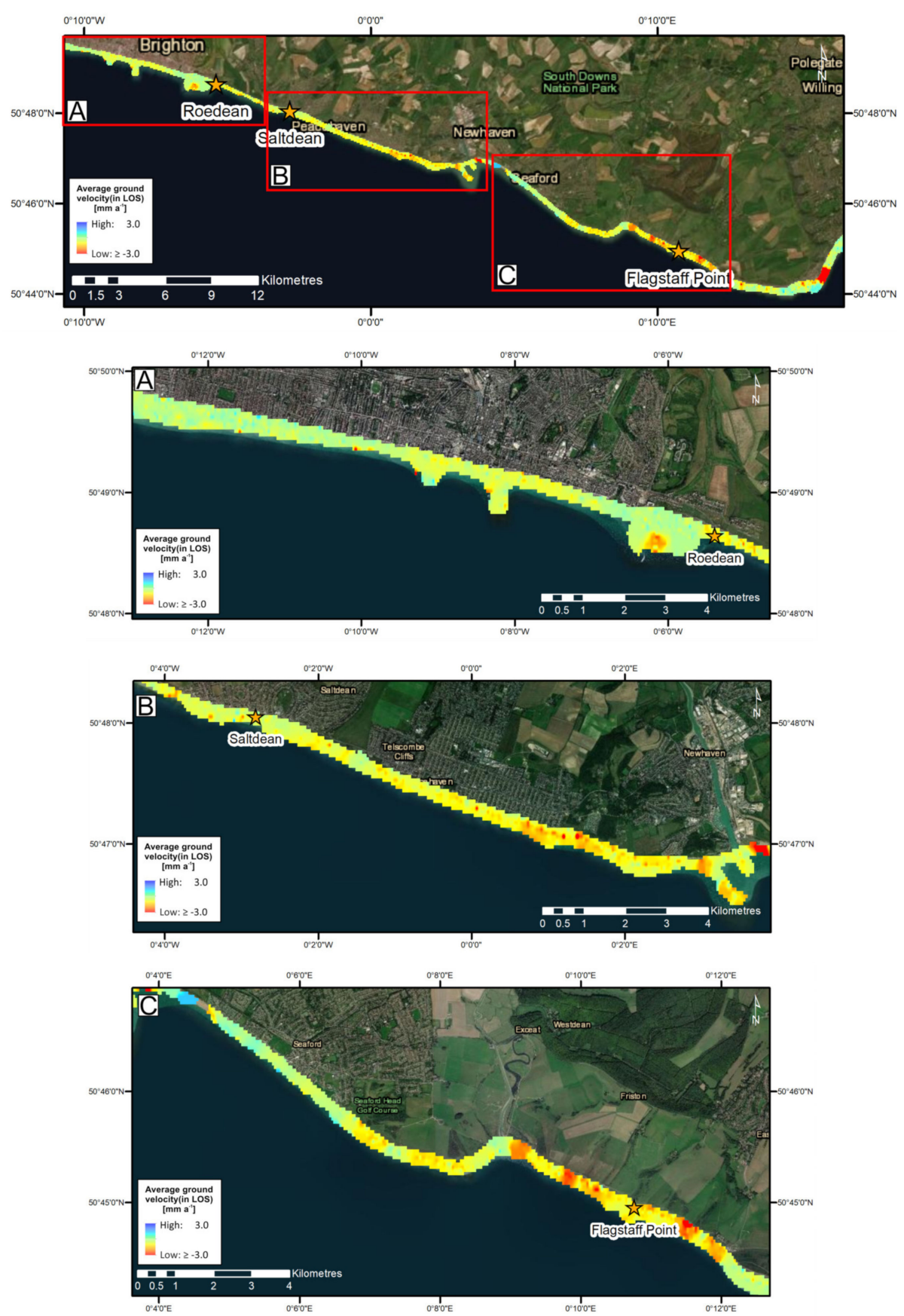

Figure 9. Regional map, presenting the average velocity for the research area from Brighton in the west to Eastbourne in the east, overlain on the ArcGIS Online World Imagery. Red colour indicates moving in the downward direction (away from the satellite), blue moving upwards (towards the satellite). Images (A), (B) and (C) present the area around the research site outlined in Section 3. (Service Layer Credits: Esri, HERE, Garmin, (C) OpenStreetMap contributors and GIS user community. Source: Esri, DigitalGlobe, GeoEye, Earthstar Geographics, CNES/Airbus DS, USDA, USGS, AeroGRID, IGN, and the GIS User Community). 
Table 2. Average velocity per annum for chalk formations exposed on the shore platform.

\begin{tabular}{cccc}
\hline Formation Name & Average Velocity $\left[\mathrm{mm} \mathrm{a}^{-\mathbf{1}}\right]$ & Number of Points Analysed & Type of Area \\
\hline Newhaven Chalk & -0.40 & 36,824 & Protected \\
Seaford Chalk & -0.66 & 3788 & Unprotected \\
Lewes Nodular Chalk & -0.53 & 1811 & Unprotected \\
\hline
\end{tabular}

Comparison with Previous Work

Established methods for monitoring platform downwearing (Section 3) are compared to PSI in Table 3. The averaged PS points are comparable with established monitoring studies for the areas. The results for Roedean show a velocity of $-1.0 \mathrm{~mm} \mathrm{a}^{-1}$. Peacehaven is calculated at $-1.27 \mathrm{~mm} \mathrm{a}^{-1}$. Hope Gap has an average of $-0.61 \mathrm{~mm} \mathrm{a}^{-1}$. All the results are within the magnitude of previous studies and confirm the validity of the PSI processing methodology.

Table 3. Surface erosion comparison between different measurement methods, updated with the results from the processing of InSAR data. Previous data table collated in Dornbusch and Robinson [42]. It should be noted that the exact position of the terrestrial measurement methods is not known.

\begin{tabular}{|c|c|c|c|c|c|}
\hline Location & Grid Reference & $\begin{array}{l}\text { Photogrammetry } \\
{\left[\mathrm{mm} \mathrm{a}^{-1}\right]}\end{array}$ & $\begin{array}{l}\text { MEM Measurements } \\
{\left[\mathrm{mm} \mathrm{a}^{-1}\right]}\end{array}$ & $\begin{array}{l}\text { Laser Scanning } \\
{\left[\mathrm{mm} \mathrm{a}^{-1}\right]}\end{array}$ & $\begin{array}{c}\operatorname{InSAR} \\
{\left[\mathrm{mm} \mathrm{a}^{-1}\right]}\end{array}$ \\
\hline Roedean & TQ 3466703136 & -0.9 to -0.1 & -3.5 & & -1.0 \\
\hline Peacehaven & TQ 4120701477 & -4.9 to -1.0 & -1.5 & -0.3 & -1.27 \\
\hline Hope Gap & TV 5104197373 & -20 to -6 & & & -0.61 \\
\hline
\end{tabular}

The results for Roedean are at the high end of the range measured with photogrammetry methods and lower than MEM. Peacehaven results using PSI are within the lower end of the photogrammetry results and compare well to the MEM measurements, but are higher than for laser scanning. At Hope Gap, the results are at the lower range of the Dornbusch and Robinson [42] photogrammetry results. The photogrammetry measurements in the paper discuss three areas for Hope Gap, which have downwearing rates that vary significantly between each other.

\subsection{Analysis of Ground Level Change at the Research Sites}

The advantage of a point-based PSI dataset is that, in addition to being able to monitor the average ground velocity values over large areas, the ground level change in time can be viewed and extracted for each PS point, so that a point-specific pattern of ground level change can be viewed as a time series at the research sites. This allows for a very detailed analysis and interpretation of the spatiotemporal patterns of ground level change. The three chosen research sites display complex patterns of change (Figures 10-12). The time series plots have been adjusted so that they all correspond to the Master Image from 24/06/2017, with a displacement equal to zero at the reference date.

\subsubsection{Roedean, East of Brighton Marina, Platform by Undercliff Walk}

The Roedean research site produced a good PS density and coverage ( $\sim 50$ points) on the platform between the groynes (Figure 10). The average annual ground level change (LoS velocity) for the entire platform in this area is $-1.0 \mathrm{~mm} \mathrm{a}^{-1}$, which is at the limit of accuracy of this technique, but the trends in the time series consistently show erosion during the analysed period of time (2015-2019), with about $4 \mathrm{~mm}$ of ground movement away from the satellite over the 3.5 years, which is well above the uncertainty level in the data. The fact that the trend is consistent over time demonstrates that the averages are realistic and reliable. All data for PS points displayed in Figure 10 have been averaged with a moving average to remove noise from the data and focus on the trend of the time series. The standard deviation has been calculated for the data and is also displayed to present the data variability. The whole area presents downward (away from the satellite) movement with time, 
starting in March 2015 until the end of the analysed period, January 2019. Small variations within the time series are visible; this is to be expected as a result of the heterogeneity of the platform, given that sediment is brought in and out of it and limited vegetation grows over the rocks.

The results for this area, showing an average ground movement of $0.98 \mathrm{~mm} \mathrm{a}^{-1}\left(\right.$ at $\left.^{2}=0.89\right)$, are comparable with results from previous studies presented in Table 1, where photogrammetry showed ground movements for Roedean between 0.1 and $0.9 \mathrm{~mm} \mathrm{a}^{-1}$ and MEM measurements showed movements of $3.5 \mathrm{~mm} \mathrm{a}^{-1}$.
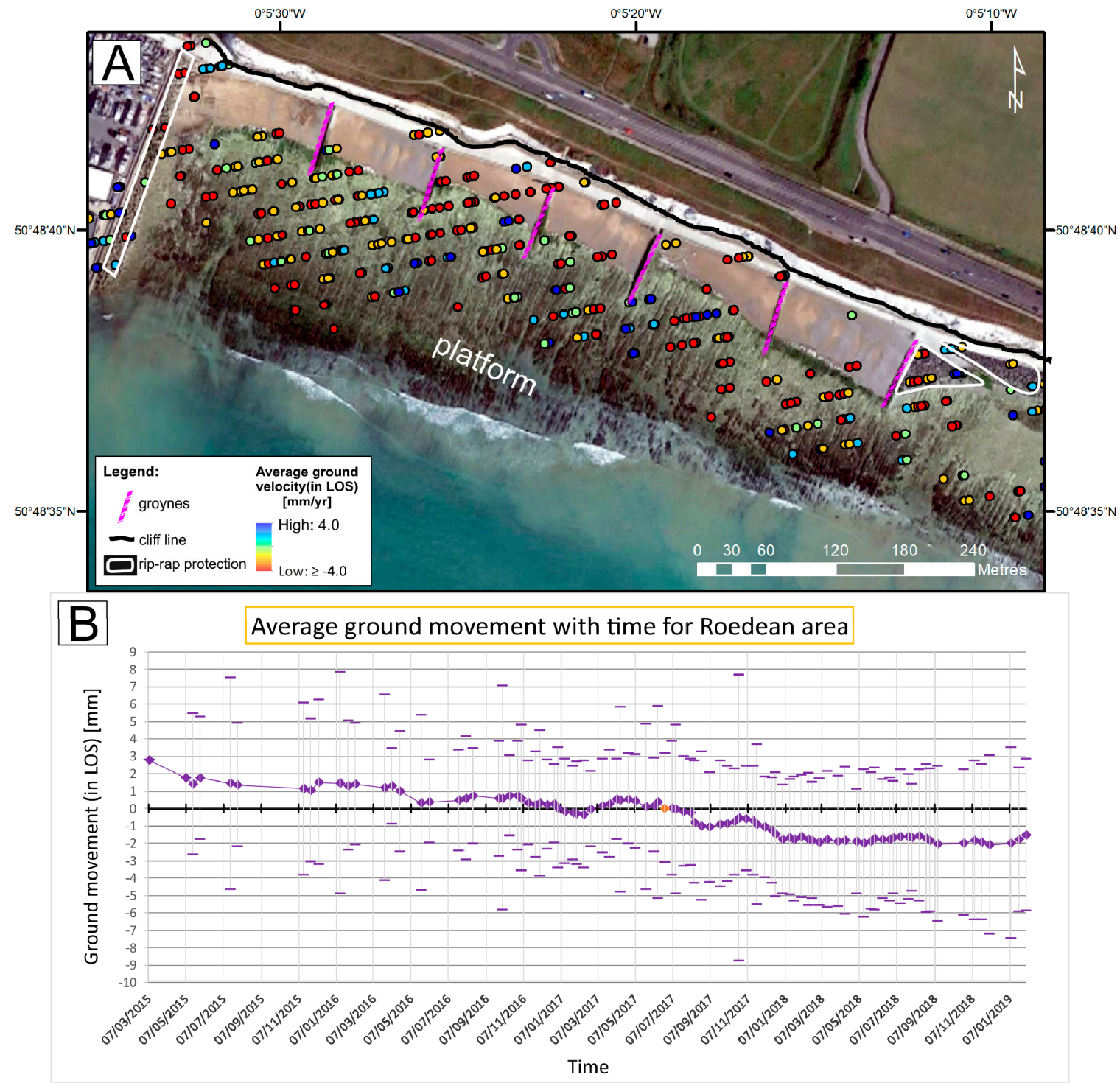

Figure 10. (A) Aerial view results for the Roedean research site, showing platform-engineered protection (seawall, splash wall, groynes and rip-rap) and the cliff line in the top image. The average velocity of the PS points is displayed on the ground in $\mathrm{mm} \mathrm{a}^{-1}$, coloured to show the general direction of the movement: red colours represent movement away from the satellite (downward), and blue colours mean movement towards the satellite (upwards). The bottom image (B) shows the average ground movement with the time for the whole area, the vertical axis displaying the ground movement in $\mathrm{mm}$, and the horizontal axis showing the time (from March 2015 until January 2019). Error bars on the plot show the standard deviation calculated for the data, presented to visualise the variability. Top image created in ArcGIS with georeferenced Google Earth Image (04/01/2019). 


\subsubsection{Saltdean}

The Saltdean platform is entirely covered in medium-to-coarse-sized gravel shingle that shifts constantly and randomly, causing a total loss of coherence between SAR observations; thus, very few PS are extracted directly on the platform in front of the undercliff walk. There are only PS points with a good coherence on the undercliff walkway, against the seawall and on the exposed chalk at the base of the seawall. Across the shore platform and on concrete defences, the average ground level change is $-0.86 \mathrm{~mm} \mathrm{a}^{-1}$ (at $\mathrm{R}^{2}=0.59$ ). The undercliff walk is a man-made structure with a $3 \mathrm{~m}$ high seawall; it is located right in front, with cemented steps ahead of it, and is followed by a platform covered with gravel (see Figure 6).

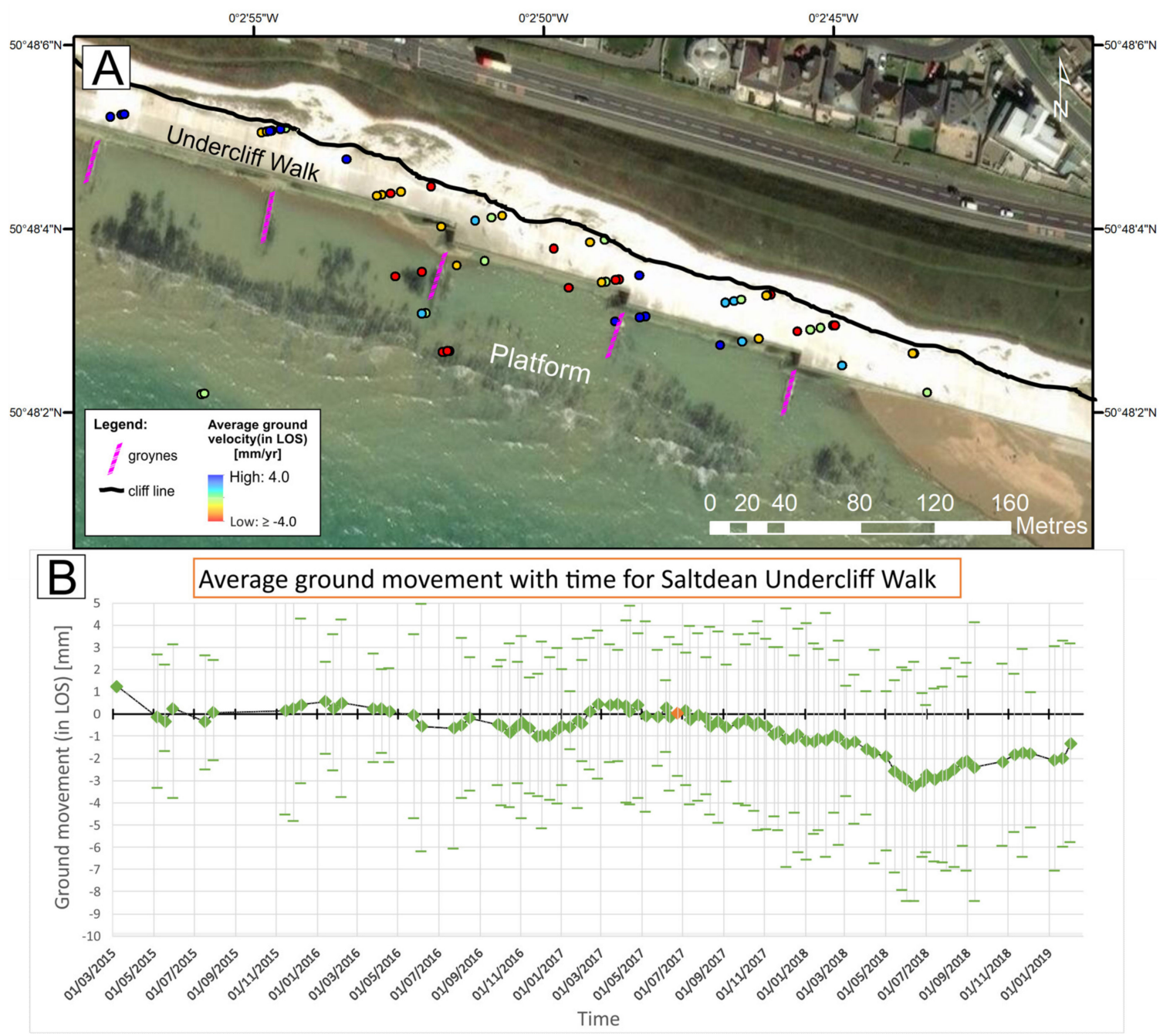

Figure 11. (A) Aerial view results for the Saltdean Undercliff Walk research site. The platform-engineered protection (seawall, groynes and rip-rap) and the cliff line, presented in the top image, show an aerial view of the area of interest, with groynes as well as the cliff line being marked. On top of the map, the average velocity of the PS points on the ground is shown in $\mathrm{mm} \mathrm{a}^{-1}$, coloured adequately to the direction of the ground movement: red colours represent movement away from the satellite (downward), and blue colours mean movement towards the satellite (upwards). The bottom image (B) shows the average ground movement with the time for the whole area, the vertical axis displaying the ground movement in $\mathrm{mm}$, and the horizontal axis showing the time frame during which the analysis was conducted (from March 2015 until January 2019). Error bars on the plot show the standard deviation calculated for the data, presented to visualise the variability. (Service Layer Credits: Esri, HERE, Garmin, (COpenStreetMap contributors and GIS user community. Source: Esri, DitalGlobe, GeoEye, Earthstar Geographics, CNES/Airbus DS, USDA, USGS, Aero GRID, IGN and GIS User Community). 
The Saltdean time series plot (Figure 11) shows considerable variation, but the dominant trend is of downward movement. The combined effects of the shingle platform covering, $30 \mathrm{~m}$ ground (spatial) resolution of the SAR data, the direction of SAR illumination (with respect to the bearing of the shoreline) and the vertical angle of the shore (with respect to the seawall) means that all the PS points are likely to be located on the seawall; this area is the brightest scatterer in the SAR imagery (see Figure 6B). The studied area of the Undercliff Walk shows a small variation in the ground movement, and the fastest movement is seen within the year 2017 until mid-2018. Downward movement in this case could be connected to the downwearing and undercutting of the chalk against the seawall, which is visible in Figure $6 \mathrm{~B}$, where a concave notch is developing.

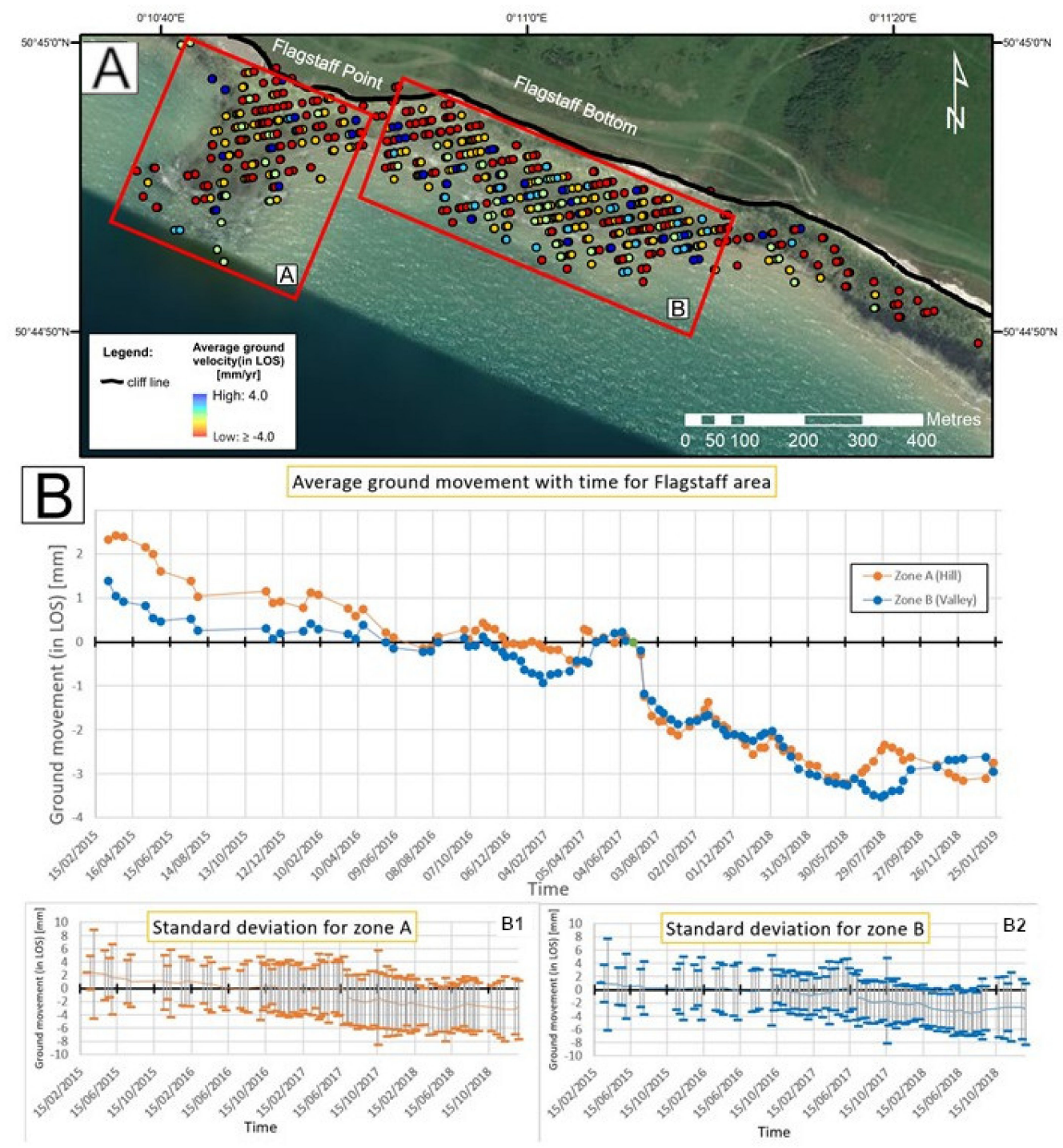

Figure 12. Results for the Flagstaff research site. (A) shows an aerial view of the research site, with the cliff line being marked. On top of the map, the average velocity of the PS points on the ground is shown in $\mathrm{mm} / \mathrm{yr}$, coloured adequately to the direction of the ground movement: red colours represent movement away from the satellite (downward), and blue colours mean movement towards the satellite (upwards). (B) shows the average ground movement with the time for the whole area, the vertical axis displaying the ground movement in $\mathrm{mm}$, and the horizontal axis showing the time frame during which the analysis was done (from March 2015 until January 2019). Error bars on the plots (B1 and B2) show the standard deviation calculated for the data, presented to visualise the variability. (Service Layer Credits: Esri, HERE, Garmin, (C) OpenStreetMap contributors and GIS user community. Source: Esri, DitalGlobe, GeoEye, Earthstar Geographics, CNES/Airbus DS, USDA, USGS, Aero GRID, IGN and GIS User Community). 


\subsubsection{Seven Sisters Platform}

Seven Sisters are a series of chalk cliffs between Seaford and Eastbourne. Counting from west to east, the fifth of the Sisters Flagstaff Point, along with the following Flagstaff Bottom (Figure 12), is an area that is notable as being the most extensive part of the platform visible at low tide; as such, it has the highest PS point density of the unprotected coastal zone. The average velocity of ground level change here is $-1.03 \mathrm{~mm} \mathrm{a}^{-1}$. As with the other research sites, a moving average is applied to the time series data to reduce the noise level, and the standard deviation is calculated and displayed on the averaged time plot to show the variation present in the data. The area is divided into two zones, A and B (Figure 12), to show the PS data in front of the hill (Flagstaff Point) and in front of the valley (Flagstaff Bottom). Zone A, in front of the hill, moves downwards slightly faster, at $-1.21 \mathrm{~mm} \mathrm{a}^{-1}$ (at $\mathrm{R}^{2}=0.90$ ), than zone $B$, which is downwearing at an average velocity of $-0.94 \mathrm{~mm} \mathrm{a}^{-1}\left(\right.$ at $\left.R^{2}=0.83\right)$. Similarly, this can be seen on the time series plot, where zone B has slightly lower ground movements than zone A. A possible explanation for these differences is the hydrodynamic regime and the longshore drift from west to east; in zone A, the extended platform and pronounced hill may be protecting zone B from platform downwearing. This will change over time as the platform in zone $\mathrm{A}$ and the cliff line are eroded, exposing zone B to more erosion.

\section{Conclusions}

This research presents a novel and complementary methodology using satellite-borne Earth Observation data to monitor, measure and quantify littoral zone platform downwearing. PSI processing was performed using 3.5 years of Sentinel-1 SAR data (acquired at low-tide times between 2015 and 2019). The results demonstrate that accurate, detailed and quantitative results can be produced on regional and local scales, over extensive areas, retrospectively and continuously over extended periods of time, to reveal the rates and patterns of ground level change across the littoral zone.

These results reveal an average ground movement of $-0.36 \mathrm{~mm} \mathrm{a}^{-1}$ across the entire research area, which is interpreted as being caused by platform erosion and downwearing. Variations in the rate of downwearing are attributable mainly to the presence or lack of engineered coastal defences on urban and rural coastal sections, respectively. Urban sections of the coast are downwearing at an average of $-0.33 \mathrm{~mm} \mathrm{a}^{-1}$ compared to rural sections, which are downwearing more rapidly at an average rate of $-1.10 \mathrm{~mm} \mathrm{a}^{-1}$. The material properties of the chalk formations in the platform were considered, and in unprotected areas the weakest chalk types (Seaford Chalk Formation) eroded at higher rates $\left(-0.66 \mathrm{~mm} \mathrm{a}^{-1}\right)$ than the more resistant Lewes Nodular Chalk Formation $\left(-0.53 \mathrm{~mm} \mathrm{a}^{-1}\right)$.

While the platform directly next to the cliff face would intuitively be expected to be eroding faster than the platform area further away from the cliffs, this signal was not detected in the data and must therefore, if present, have been below the detection limits of ca. $1 \mathrm{~mm} \mathrm{a}^{-1}$.

At local scales, the detailed results for three research sites chosen to represent a range of different environments and settings show small but consistent trends of ground level change. These results are consistent with prior point-based studies and reveal that, despite the presence of coastal defences (urban sections), all areas still experience measurable and steady downwearing.

The use of PSI offers a new, cost-effective methodology for coastal monitoring that is complementary to more conventional in situ methods, provides a synoptic perspective and can reveal spatial and temporal patterns of change.

Only using SAR data acquired at low-tide times reduces the number of available scenes by $50 \%$ but allows the number of generated high-coherence PS points to nearly quadruple.

The spatial variations in the platform downwearing rates and amounts at the research sites show that coastal defences are, in general, successful in limiting erosion, but they also show that undercutting of seawall foundations may be occurring at certain key sites.

Conventional direct and indirect methods for measuring downwearing are considered extremely valuable and, if used effectively in conjunction with PSI, could provide a powerful and cost-effective solution to the need to quantify and characterise coastal zone change over large areas. PSI monitoring 
offers a continuous, noninvasive and near-real-time solution, which is as useful in densely populated areas as in rural ones and could prove an invaluable tool for coastal researchers, engineers and planners.

Author Contributions: Conceptualization, G.M., J.L., P.M. and R.G.; methodology, G.M.; software, G.M.; validation, G.M.; formal analysis, G.M.; investigation, G.M.; resources, G.M., J.L., P.M., R.G.; data curation, G.M.; writing-original draft preparation, G.M.; writing—review and editing, G.M., J.L., P.M. and R.G.; visualization, G.M. and P.M.; supervision, J.L., P.M. and R.G.; project administration, J.L., P.M. and R.G.; funding acquisition, J.L., P.M. and R.G. All authors have read and agreed to the published version of the manuscript.

Funding: This research was funded by Engineering and Physical Sciences Research Council (EPSRC), grant number EP/L016826/1 and by Skempton Scholarship. The APC was funded by Research Council UK (RCUK).

Acknowledgments: This research has been conducted as part of a PhD funded by EPSRC (UK) and Skempton Scholarship. The authors would like to thank Brighton and Hove City Council for their support and feedback.

Conflicts of Interest: The authors declare no conflict of interest.

\section{References}

1. Evans, E.; Ashley, R.; Hall, J.; Penning-Rowsell, E.; Sayers, P.; Thorne, C.; Watkinson, A. Foresight: Future Flooding: Scientific Summary: Volume I: Future Risks and Their Drivers; Government Office for Science: London, UK, 2004.

2. Howard, T.; Palmer, M.; Guentchev, G.; Krijnen, J. Exploratory Sea Level Projections for the UK to 2300; Environment Agency: Bristol, UK, 2019; p. 98.

3. Dornbusch, U.; Moses, C.; Robinson, D.A.; Williams, R. Soft copy photogrammetry to measure shore platform erosion on decadal timescales. J. Coast. Conserv. 2008, 11, 193-200. [CrossRef]

4. Moses, C.; Robinson, D.; Barlow, J. Methods for measuring rock surface weathering and erosion: A critical review. Earth-Science Rev. 2014, 135, 141-161. [CrossRef]

5. Cullen, N.D.; Verma, A.; Bourke, M.C. A comparison of structure from motion photogrammetry and the traversing micro-erosion meter for measuring erosion on shore platforms. Earth Surf. Dyn. 2018, 6, 1023-1039. [CrossRef]

6. Swantesson, J.O.H. Recent microweathering phenomena in southern and central Sweden. Processes 1992, 3, 275-292. [CrossRef]

7. BSI. BS 5930: 2015: Code of Practice for Ground Investigations; British Standards Institution: London, UK, 2015.

8. Xue, F.; Lv, X.; Dou, F.; Yun, Y. A review of time-series Interferometric SAR techniques: A tutorial for surface deformation analysis. IEEE Geosci. Remote. Sens. Mag. 2020, 8, 22-42. [CrossRef]

9. Massonnet, D.; Rossi, M.; Carmona, S. The displacement field of the Landers earthquake mapped by radar interferometry. Nat. Cell Biol. 1993, 364, 138-142. [CrossRef]

10. Gabriel, A.K.; Goldstein, R.M.; Zebker, H.A. Mapping small elevation changes over large areas: Differential radar interferometry. J. Geophys. Res. Space Phys. 1989, 94, 9183. [CrossRef]

11. Massironi, M.; Zampieri, D.; Bianchi, M.; Schiavo, A.; Franceschini, A. Use of PSInSAR ${ }^{\text {TM }}$ data to infer active tectonics: Clues on the differential uplift across the Giudicarie belt (Central-Eastern Alps, Italy). Tectonophysics 2009, 476, 297-303. [CrossRef]

12. Colesanti, C.; Wasowski, J. Investigating landslides with space-borne Synthetic Aperture Radar (SAR) interferometry. Eng. Geol. 2006, 88, 173-199. [CrossRef]

13. Kiseleva, E.; Mikhailov, V.; Smolyaninova, E.; Dmitriev, P.; Golubev, V.; Timoshkina, E.; Hooper, A.; Samiei-Esfahany, S.; Hanssen, R. PS-InSAR monitoring of landslide activity in the black sea coast of the Caucasus. Procedia Technol. 2014, 16, 404-413. [CrossRef]

14. Dong, J.; Zhang, L.; Tang, M.; Liao, M.; Xu, Q.; Gong, J.; Ao, M. Mapping landslide surface displacements with time series SAR interferometry by combining persistent and distributed scatterers: A case study of Jiaju landslide in Danba, China. Remote Sens. Environ. 2018, 205, 180-198. [CrossRef]

15. Velasco, V.; Sanchez, C. Ground deformation mapping and monitoring of salt mines using InSAR technology. In Proceedings of the Solution Mining Research Institute Fall 2017 Technical Conference, Münster, Germany, 24-27 September 2017.

16. Gonzáles-Martí, J.; Nevard, S.; Sánchez, J. The Use of InSAR (Interferometric Synthetic Aperture Radar) to Complement Control of Construction and Protect Third Party Assets; Crossrail Learning Legacy Report; Crossrail Ltd: London, UK, 2017. 
17. Giardina, G.; Milillo, G.; DeJong, M.; Perissin, D.; Milillo, G. Evaluation of InSAR monitoring data for post-tunnelling settlement damage assessment. Struct. Control Health Monit. 2018, 26, e2285. [CrossRef]

18. Milillo, P.; Giardina, G.; DeJong, M.; Perissin, D.; Milillo, G. Multi-temporal InSAR structural damage assessment: The London crossrail case study. Remote. Sens. 2018, 10, 287. [CrossRef]

19. Bischoff, C.A.; Ghail, R.C.; Mason, P.J.; Ferretti, A.; Davis, J.A. Photographic feature: Revealing millimetre-scale ground movements in London using SqueeSAR ${ }^{\mathrm{TM}}$. Q. J. Eng. Geol. Hydrogeol. 2019. [CrossRef]

20. Scoular, J.; Croft, J.; Ghail, R.; Mason, P.J.; Lawrence, J.; Stoianov, I. Limitations of Persistent Scatterer Interferometry to measure small seasonal ground movements in an urban environment. Q. J. Eng. Geol. Hydrogeol. 2019, 53, 39-48. [CrossRef]

21. Scoular, J.; Ghail, R.; Mason, P.J.; Lawrence, J.; Bellhouse, M.; Holley, R.; Morgan, T. Retrospective InSAR analysis of East London during the construction of the lee tunnel. Remote. Sens. 2020, 12, 849. [CrossRef]

22. Ciampalini, A.; Solari, L.; Giannecchini, R.; Galanti, Y.; Moretti, S. Evaluation of subsidence induced by long-lasting buildings load using InSAR technique and geotechnical data: The case study of a Freight Terminal (Tuscany, Italy). Int. J. Appl. Earth Obs. Geoinf. 2019, 82, 82. [CrossRef]

23. Sousa, J.J.; Ruiz, A.M.; Hanssen, R.F.; Bastos, L.; Gil, A.J.; Galindo-Zaldivar, J.; De Galdeano, C.S. PS-InSAR processing methodologies in the detection of field surface deformation-Study of the Granada basin (Central Betic Cordilleras, southern Spain). J. Geodyn. 2010, 49, 181-189. [CrossRef]

24. Pratesi, F.; Tapete, D.; Del Ventisette, C.; Moretti, S. Mapping interactions between geology, subsurface resource exploitation and urban development in transforming cities using InSAR Persistent Scatterers: Two decades of change in Florence, Italy. Appl. Geogr. 2016, 77, 20-37. [CrossRef]

25. Rohmer, J.; Raucoules, D. On the applicability of Persistent Scatterers Interferometry (PSI) analysis for long term $\mathrm{CO}_{2}$ storage monitoring. Eng. Geol. 2012, 147, 137-148. [CrossRef]

26. Rohmer, J.; Loschetter, A.; Raucoules, D.; de Michele, M.; le Gallo, Y.; Raffard, D. Improving Persistent Scatterers Interferometry (PSI) analysis in highly vegetal/agricultural areas for long term $\mathrm{CO}_{2}$ storage monitoring. Energy Procedia 2014, 63, 4019-4026. [CrossRef]

27. Stavrou, A.; Lawrence, J.A.; Mortimore, R.N.; Murphy, W. A geotechnical and GIS based method for evaluating risk exposition along coastal cliff environments: A case study of the chalk cliffs of southern England. Nat. Hazards Earth Syst. Sci. 2011, 11, 2997-3011. [CrossRef]

28. Moses, C.A. Chapter 4 The Rock Coast of the British Isles: Shore Platforms; Geological Society: London, UK, 2014; Volume 40, pp. 39-56.

29. Lord, J.A.; Clayton, C.R.I.; Mortimore, R.N. Engineering in Chalk; CIRIA: London, UK, 2002.

30. Mortimore, R.N. Logging the Chalk; Whittles Publishing: Caithness, Scotland, 2014; pp. 48-117.

31. Lawrence, J.; Mortimore, R.; Stone, K.; Busby, J. Sea saltwater weakening of chalk and the impact on cliff instability. Geomorphology 2013, 191, 14-22. [CrossRef]

32. Lawrence, J.; Spence, R.; Mortimore, R.N.; Eade, M.; Bottrell, S.H. Coastal cliff rock mass weakening of Chalk and the impact of salt water. Proc. Inst. Civ. Eng. Geotech. Eng. 2018, 171, 545-555. [CrossRef]

33. Mider, G.; Lawrence, J. Anisotropic Permeability of Chalk, in Engineering in Chalk; ICE: London, UK, 2018; pp. 481-487.

34. Mortimore, R.N.; Stone, K.J.; Lawrence, J.; Duperret, A. Chalk Physical Properties and Cliff Instability; Geological Society, London, Engineering Geology Special Publications: London, UK, 2004; Volume 20, pp. 75-88.

35. Aliyu, M.M.; Murphy, W.; Lawrence, J.A.; Collier, R. Engineering geological characterization of flints. Q. J. Eng. Geol. Hydrogeol. 2017, 50, 133-147. [CrossRef]

36. Robinson, L.A. The micro-erosion meter technique in a littoral environment. Mar. Geol. 1976, 22, M51-M58. [CrossRef]

37. Stephenson, W.J.; Finlayson, B. Measuring erosion with the micro-erosion meter-Contributions to understanding landform evolution. Earth-Science Rev. 2009, 95, 53-62. [CrossRef]

38. Swantesson, J.; Moses, C.; Berg, G.E.; Jansson, K. Methods for measuring shore platform micro erosion: A comparison of the micro-erosion meter and laser scanner. Z. fur Geomorphol. Suppl. 2006, 144, 1-17.

39. Swantesson, J.O.H. Weathering and erosion of rock carvings in Sweden during the period 1994-2003-Micro mapping with laser scanner for assessment of breakdown rates. In Department of Physical Geology, Division for Environmental Sciences; Karlstad University: Karlstad, Sweden, 2005.

40. Ellis, N. Morphology, Process and Rates of Denudation on the Chalk Shore Platform of East Sussex; Polytechnic: Brighton, UK, 1986. 
41. Dornbusch, U.; Robinson, D.A.; Williams, R.B.; Moses, C.A. Chalk shore platform erosion in the vicinity of sea defence structures and the impact of construction methods. Coast. Eng. 2007, 54, 801-810. [CrossRef]

42. Dornbusch, U.; Robinson, D.A.; Williams, R.B.; Moses, C. Block removal and step backwearing as erosion processes on rock shore platforms: A preliminary case study of the chalk shore platforms of south-east England. Earth Surf. Process. Landf. 2010, 36, 661-671. [CrossRef]

43. Ferretti, A.; Prati, C.; Rocca, F. Permanent scatterers in SAR interferometry. IEEE Trans. Geosci. Remote. Sens. 2001, 39, 8-20. [CrossRef]

44. Crosetto, M.; Monserrat, O.; Cuevas-González, M.; Devanthéry, N.; Crippa, B. Persistent scatterer interferometry: A review. ISPRS J. Photogramm. Remote. Sens. 2016, 115, 78-89. [CrossRef]

45. Ferretti, A.; Monti-Guarnieri, A.; Prati, C.; Rocca, F.; Massonet, D. InSAR Principles: Guidelines for SAR Interferometry Processing and Interpretation; Fletcher, K., Ed.; ESA Publications: Noordwijk, The Netherlands, 2007.

46. Crosetto, M.; Monserrat, O.; Jungner, A.; Crippa, B. Persistent scatterer interferometry: Potential and limits. In Proceedings of the 2009 ISPRS Workshop on High-Resolution Earth Imaging for Geospatial Information, Hannover, Germany, 2-5 June 2009.

(C) 2020 by the authors. Licensee MDPI, Basel, Switzerland. This article is an open access article distributed under the terms and conditions of the Creative Commons Attribution (CC BY) license (http://creativecommons.org/licenses/by/4.0/). 